\title{
Icelandic accession of Arabidopsis thaliana confirmed with cytogenetic markers and its origin inferred from whole-genome sequencing
}

\author{
Terezie Mandáková ${ }^{1}$, Huörtur Thorbjörnsson ${ }^{2}$, Rahul Pisupati $^{3}$, Ilka Reichardt ${ }^{3}$, \\ Martin A. LySaK ${ }^{1}$, Kesara AnamthaWat-JónSSON ${ }^{4 *}$ \\ ${ }^{\text {I} C E I T E C ~-~ C e n t r a l ~ E u r o p e a n ~ I n s t i t u t e ~ o f ~ T e c h n o l o g y, ~ M a s a r y k ~ U n i v e r s i t y, ~ K a m e n i c e ~ 5, ~ 62500 ~ B r n o, ~ C z e c h ~ R e p u b l i c ~}$ \\ ${ }^{2}$ Reykjavik Botanic Garden, Laugardalur, Reykjavik, IS-104, Iceland \\ ${ }^{3}$ Gregor Mendel Institute (GMI), Austrian Academy of Sciences, Vienna Biocenter (VBC), Dr Bohr-Gasse 3, 1030 Vienna, \\ Austria \\ ${ }^{4}$ Institute of Life and Environmental Sciences, University of Iceland, Askja, Sturlugata 7, Reykjavik, IS-101, Iceland \\ *Corresponding author: e-mail kesara@hi.is
}

\begin{abstract}
In this paper, we report the first discovery of Arabidopsis thaliana in Iceland. In May 2015, the plants were located growing on warm geothermal soil around the hot spring Deildartunguhver in Reykholt, West Iceland. Flower buds and leaves were collected and used for subsequent cytogenetic analyses and DNA sequencing. Whole plant specimens were deposited at the Icelandic AMNH herbarium and were assigned accession number VA21379. The accession was found to be diploid with $2 n=2 x=10$, as expected for this species. At meiosis I (diakinesis) it formed five normal bivalents. Ribosomal FISH mapping revealed two pairs of 5S rDNA loci and two pairs of NORs. Fine-scale chromosome painting using BAC clones specific for chromosomes At1 and At4 confirmed the standard structure of these chromosomes. Furthermore, the painting revealed an absence of the 1.17-Mb paracentric inversion on the At4 short arm in the Icelandic accession, in contrast to the inversionbearing $A$. thaliana accessions more prevalent in North America. The sequencing of multiplexed whole-genome libraries identified the Swedish accession Ham-1 as the closest relative of the Icelandic accession, with, however, a markedly low SNPmatch score. We conclude that although the Icelandic accession appears to be more genetically related to populations from Scandinavia than to other European accessions, it did not originate from any of the populations represented in the global collection of the 1001 Genomes accessions of $A$. thaliana.
\end{abstract}

Keywords: Brassicaceae; chromosome painting; comparative cytogenomics; geothermal soil; meiosis; ribosomal FISH; paracentric inversion; SNPmatch

\section{YFIRLIT}

Stofn gøesamatar (Arabidopsis thaliana) frá Íslandi greindur með aðferðum frumuerfðafræðði og raðgreiningu erfðamengis.

Hér verður greint frá fyrsta fundi gæsamatar (Arabidopsis thaliana) á Íslandi. Tegundin fannst í maí 2015 á jarðhitasvæði við Deildartunguhver. Blómknöppum og laufblöðum var safnað fyrir litningagreiningu og raðgreiningu erfðamengis. Einnig var eintökum safnað til purrkunar og peim síðan komið fyrir í plöntusafni AMNH par sem pau fengu númerið VA21379. Eins og fyrri rannsóknir gæsamatar hafa leitt í ljós reyndust sýnin vera tvílitna $(2 \mathrm{n}=2 \mathrm{x}=10)$ og við greiningu á rýriskiptingu komu í ljós fimm eðlileg tvígilda litningapör. Páttatenging flúrljómandi rDNA (FISH) preifara á litningum í mítósu leiddi í ljós tvö $5 \mathrm{~S}$ ríbósóm genapör og 
tvö pör NOR svæða sem jafnframt eru dæmigerð fyrir arfgerð tegundarinnar. Nánari greining með notkun BACFISH preifara á litningunum At1 og At4 sýndi að uppbygging litninganna úr sýnunum frá Deildartungu væri eðlileg. Greiningin leiddi jafnframt í ljós vöntun á 1.17-Mb práðhefta umhverfu á At4 litningi en pessi umhverfa er algeng meðal stofna gæsamatar í Norður-Ameríku. Raðgreining erfðamengis íslensku sýnanna leiddi í ljós mestan skyldleika við sýni frá Svíbjóð en pó með lágum skyldleikastuðli. Pví er niðurstaða pessarar greiningar sú að pótt plöntur sem fundust á Íslandi séu skyldari stofnum frá Skandinavíu en stofnum annars staðar frá, hafa pær upphaflega ekki borist frá neinum af stofnum í pekktu safni 1001 erfðamengja gæsamatar víðsvegar að úr heiminum.

\section{INTRODUCTION}

Arabidopsis thaliana (L.) Heynh. is an important model organism for studying plant genetics and for elucidating physiological, cellular and molecular processes of plant growth and development (Rédei 1975, Meyerowitz \& Pruitt 1985, Koornneef \& Meinke 2010). In laboratories, the species can easily be cultivated in a controlled environment. By far the most common ecotypes adopted for research purposes include Columbia $(\mathrm{Col})$, from which the first $A$. thaliana genome was sequenced (The Arabidopsis Genome Initiative, 2000), Landsberg erecta (Ler), and to a lesser extent, Wassilewskija (Ws) and Cape Verde Islands
(Cvi).

Since the emergence of $A$. thaliana forty years ago as a model organism for research in plant biology, numerous collections of natural accessions and inbred lines of $A$. thaliana have been established. To date, a total of 1,135 accessions from a worldwide hierarchical collection, representing both the native Eurasian and North African range, and recently colonized North American, have been sequenced or re-sequenced. The impressive dataset has revealed, for example, considerable genetic and phenotypic variation within species, postglacial evolutionary history and expansion of the species, and has provided insights into

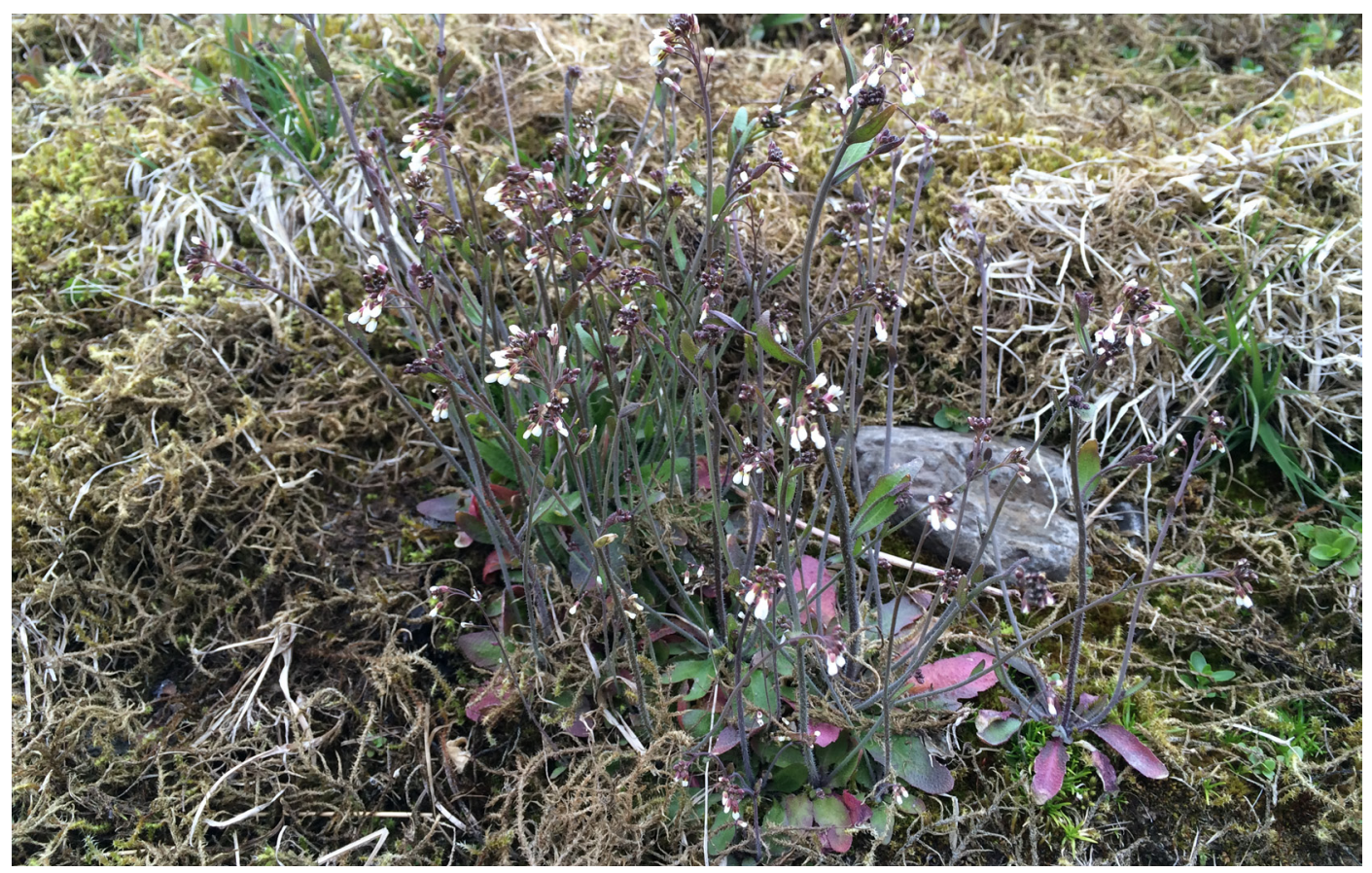

Figure 1. Arabidopsis thaliana plants growing on warm geothermal soil around the hot spring Deildartunguhver in Reykholt, West Iceland. 
the genetic basis of adaptation to different environments (The 1001 Genomes Consortium 2016).

Arabidopsis thaliana is an annual herb, a member of the mustard family (Brassicaceae), with its native distribution range covering almost all of Europe to central Asia, and is now naturalized worldwide (Ball 1993, Al-Shehbaz \& O'Kane 2002). The plant grows readily and often pioneers open or disturbed habitats, sandy soil, river banks, roadsides, rocky slopes, waste places, cultivated ground, meadows, and slightly alkaline flats, growing under shrubs and in open areas, from sea level to $3,400 \mathrm{~m}$, under a broad range of climatic conditions (Al-Shehbaz \& O'Kane 2002, Hoffmann 2002).

Iceland is not on any of the distribution maps of A. thaliana (e.g. Ball 1993, Al-Shehbaz \& O'Kane 2002, NPGS 2016). Although Arabidopsis lyrata subsp. petraea (L.) O'Kane \& Al-Shehbaz [Arabidopsis petraea (L.)] is common, A. thaliana is absent in the vascular flora of Iceland (Kristinsson 2008, Flora of Iceland 2016a). During our botanical excursion in May 2015, however, we found A. thaliana growing in Iceland (Figure 1). Numerous individual plants were found growing on a geothermal soil around the hot spring Deildartunguhver, Deildartunga region in Reykholt, West Iceland, at $64.6638^{\circ} \mathrm{N} /$ $21.4104^{\circ} \mathrm{W}$, about 30 ma.s.l. The site was revisited one month later to collect whole plant samples for herbarium preparation. The specimens from this discovery were deposited by the authors of this paper at the AMNH Herbarium of the Icelandic Institute of Natural History, Akureyri Division, and were collectively assigned accession number VA21379.

The objective of the present study was to confirm the species identity using molecular and cytogenetic approaches.

\section{MATERIALS AND METHODS}

Whole Arabidopsis thaliana plants were collected in the field, pressed and dried for preparation of herbarium specimens, and two were sent to the Gregor Mendel Institute in Vienna for sequencing. For chromosome preparations, inflorescences with young flower buds were collected in fixative (3:1 ratio of ethanol 96\% and glacial acetic acid) and kept cold until analysis. Seeds of the Icelandic accession will be made publically available to the scientific community via the Nottingham Arabidopsis Stock Centre (NASC).

\section{Chromosome preparation and cytogenetic analysis}

Mitotic and meiotic chromosome preparations were prepared as described in Mandáková \& Lysak (2016a). Chromosome preparations were treated with $100 \mu \mathrm{g} / \mathrm{ml}$ RNase in $2 \times$ sodium saline citrate (SSC; 20× SSC: $3 \mathrm{M}$ sodium chloride, $300 \mathrm{mM}$ trisodium citrate, $\mathrm{pH}$ 7.0) for $60 \mathrm{~min}$ and with $0.1 \mathrm{mg} / \mathrm{ml}$ pepsin in $0.01 \mathrm{M}$ $\mathrm{HCl}$ at $37^{\circ} \mathrm{C}$ for $5 \mathrm{~min}$; then post-fixed in $4 \%$ formaldehyde in $2 \times \mathrm{SSC}$ for $10 \mathrm{~min}$, washed in $2 \times \mathrm{SSC}$ twice for $5 \mathrm{~min}$, and dehydrated in an ethanol series $(70 \%, 90 \%$, and $100 \%, 2$ min each). A. thaliana BAC clone T15P10 (AF167571) bearing 45S rRNA gene repeats was used for in situ localization of 45S rDNA, and A. thaliana clone pCT 4.2 (M65137), corresponding to a 500-bp 5S rRNA repeat, were used for localization of $5 \mathrm{~S}$ rDNA loci. For painting of chromosome 1 (At1) and the upper arm of chromosome 4 (At4), chromosomespecific BAC clones of $A$. thaliana were used (Arabidopsis Biological Resource Center, Columbus, OH). All DNA probes were labelled with biotin-dUTP, digoxigenin-dUTP, or Cy3-dUTP by nick translation as described in Mandáková \& Lysak (2016b). Selected labelled DNA probes were pooled together, ethanol precipitated, dissolved in a $20 \mu$ mixture containing $50 \%$ formamide, $10 \%$ dextran sulphate and $2 \times \mathrm{SSC}$, and pipetted onto each of the microscopic slides. The slides were heated at $80^{\circ} \mathrm{C}$ for $2 \mathrm{~min}$ and incubated at $37^{\circ} \mathrm{C}$ overnight. Hybridized probes were visualized either as the direct fluorescence of Cy3-dUTP (yellow) or through fluorescently-labelled antibodies against biotin-dUTP (red) and digoxigenindUTP (green) as in Mandáková \& Lysak (2016b). Chromosomes were counterstained with 4,6-diamidino-2-phenylindole (DAPI, 2 
$\mu \mathrm{g} / \mathrm{ml}$ ) in Vectashield antifade. Fluorescence signals were visualized in a Zeiss Axioimager epifluorescence microscope and images with $1,360 \times 1,024$ pixels were captured using CoolCubelm camera (MetaSystems). Individual images were merged and processed using Photoshop CS software (Adobe Systems).

\section{Multiplexed library preparation}

DNA from two Icelandic plants was extracted by the NucleoMag Plant Kit (Macherey Nagel). Libraries were prepared as described in Baym et al. (2015). Briefly, $2.5 \mathrm{ng}$ of DNA was fragmented and adapter-(tagmentation-based) ligated in a $2.5 \mu \mathrm{l}$ reaction volume using the Illumina Nextera ${ }^{\mathrm{TM}}$ Kit. Libraries were amplified by Illumina TrueSeq Primers and VeraSeq High Fidelity DNA Polymerase (BiozymTC). Size selection and PCR clean-up was performed with Agencourt AMPure Beads (Beckman Coulter). Libraries were validated with a Fragment Analyzer ${ }^{\mathrm{TM}}$ Automated CE System (Advanced Analytical), pooled in equimolar concentration and spiked into 96x-multiplex flow cells. Libraries were then sequenced on the Illumina HiSeq ${ }^{\mathrm{TM}} 2000$ Analyzer using the manufacturer's standard cluster generation and sequencing protocols in $125 \mathrm{bp}$ PE mode.

\section{Sequencing analysis}

We aligned the sequencing results to the TAIR 10 reference genome (The Arabidopsis Information Resource 2016) and called single nucleotide polymorphisms (SNPs) using GATK Haplotype Caller with suggested best practices. We filtered for biallelic SNPs and performed the genotyping using SNPmatch (Pisupati et al. 2017). Briefly, SNPmatch calculates a score (probability of match) with each accession present in the database (The 1001 Genomes Consortium 2016). We also performed this algorithm across $300 \mathrm{~kb}$ windows along the genome.

\section{RESULTS AND DISCUSSION \\ Botanical identification, ecology and site description \\ Arabidopsis thaliana plants at Deildartunga}

were found in a patch approximately $4 \mathrm{~m}$ long and $2 \mathrm{~m}$ wide, where the highest density of plants was alongside and on a gravel path, up to about 50 plants per square metre. The botanical description of the Icelandic accession of Arabidopsis thaliana from Deildartunga (Figure 1, accession no. VA21379) corresponds correctly with the description in florae (e.g. Ball 1993, Flora of China 2016). A. thaliana is an erect annual (rarely biennial) plant, usually growing to $20-25 \mathrm{~cm}$ tall. Basal leaves form a rosette, where one to a few simple or branched flowering stems develop. The basal leaves are shortly petiolate, up to $4.5 \mathrm{~cm}$ long and $15 \mathrm{~mm}$ wide, have trichomes, and their margins are entire to dentate. Stem leaves are sessile, up to $2.5 \mathrm{~cm}$ long and $10 \mathrm{~mm}$ wide, and their margins are usually entire. Petals are white and 2-3.5 mm long. Siliques are 5-20 mm long and glabrous.

Deildartunguhver is Europe's most powerful hot spring, providing around $180 \mathrm{~L} / \mathrm{sec}$ of $97^{\circ} \mathrm{C}$ hot water. Most of the water used for central heating in the towns of Borgarnes and Akranes is taken from this hot spring (Náttúran 2016). The geothermal area around this hot spring supports a relatively rich herbaceous vegetation that is typical of moist habitats such as bogs and marshes. In this hot spring area, mosses are the most prevalent component of the vegetation (Figure 1). According to the thorough survey commissioned by the Icelandic Institute of Natural History (Kristinsson et al. 2007), mosses and bryophytes together formed $50-84 \%$ of the total vegetation, whereas the most common vascular plants included alpine marsh violet (Viola palustris L.), marsh pennywort (Hydrocotyle vulgaris L.) and autumn hawkbit (Leontodon autumnalis L.). The latter species was found more peripherally, in an open, somewhat disturbed habitat. Due to the geothermal activity and the occurrence of rare species, the area has been visited regularly and its flora investigated (e.g. Kristinsson et al. 2007); however, no $A$. thaliana was ever found, not even in visits in 2012 and 2013 (Rannveig Thoroddsen pers. comm.). In late summer 2015, a visitor reported to the Icelandic Institute of Natural History the occurrence of $A$. thaliana 
at exactly the same location as we did (Pawel Wasowicz, pers. comm.). As A. thaliana is known to be successful at colonizing areas that have undergone human-mediated disturbance, it is suspected that the establishment of the species in this location is quite recent. The area is becoming increasingly more disturbed, a result of horticulture, experimental drilling for thermal water and the growing of lawn grass for access to the hot spring, essentially for tourism.

Geothermal soil is usually a few to several degrees warmer than the ground in nearby areas, due to radiated heating from geothermal water channels that are present in the bedrock. Moderate soil warming promotes plant growth through an active root system and a healthy underground network of microorganisms, but too much will have negative effects, as shown, for example, in the study of soil warming at Reykir in Ölfus, South Iceland (O'Gorman et al. 2014). It is therefore expected that many plants growing on geothermal soil are either not able to grow in colder environments or they are species particularly adapted to a geothermal habitat. Thermophilic species, such as scabiosa (Succica pratensis Moench), require a higher average summer temperature with a long growing season, i.e., the growth begins earlier in the spring and lasts longer into the autumn (Kristinsson 2015). Some thermophilic species grow exclusively on geothermal soil, for example, marsh pennywort (Hydrocotyle vulgaris), found also at Deildartunga. This type of species depends more on ground than on air temperature. In most natural habitats, $A$. thaliana is a winter annual. Its seeds germinate in the autumn and the young plants survive the winter. Floral meristems emerge in the spring and only the seeds survive the summer months (Baskin \& Baskin 1972). The growth of $A$. thaliana in Iceland may be due to the winter survival of seedlings in the warm, geothermal soil.

\section{Identity of the Icelandic accession confirmed}

To corroborate the identification of the Icelandic Arabidopsis accession, the plants were analysed cytogenetically. In DAPI-stained mitotic and meiotic chromosome spreads, ten chromosomes and five chromosome pairs were confirmed, respectively (Figures 2A, E). Meiotic chromosome pairing was normal, forming five bivalents (Figure 2E). FISH with probes for $5 \mathrm{~S}$ and $45 \mathrm{~S}$ rDNA identified two pairs of $5 \mathrm{~S}$ rDNA loci and two pairs of nucleolar organizing regions (NORs); one pair of NORs co-localized with two 5S rDNA loci (Figure 2A). This pattern is congruent with the distribution of rDNA major loci in the $A$. thaliana genome (Maluszynska \& Heslop-Harrison 1991, Murata et al. 1997, Fransz et al. 1998, Koornneef et al. 2003).

The karyotype of the Icelandic accession was further characterized by chromosome painting (CP) using BAC clones specific for chromosomes At1 and At4. Pachytene $\mathrm{CP}$ analysis showed that both large-scale (Figure 2B) and detailed BACby-BAC structures of chromosome Atl (Figure 2C) fully corresponded to the BAC tiling path of this chromosome (Pecinka et al. 2004). CP also revealed the structure of the upper (short) arm of chromosome At4 and showed that the Icelandic accession does not belong to the group of A. thaliana ecotypes bearing a paracentric 1.17$\mathrm{Mb}$ inversion on the short arm of At4 (Figure 2D, Fransz et al. 2016).

This paracentric $1.17-\mathrm{Mb}$ inversion has led to the formation of a knob-like structure (heterochromatic knob hk4S) on the short arm of chromosome At4, and among the laboratory accessions, it is present in Col-0 and Ws-2, but absent in Ler and C24 (Fransz et al. 1998). As the Icelandic accession does not carry the inversion, it is termed "knobless". The SNP study and examination of the RegMap panel and the 1,001 Arabidopsis genomes (Fransz et al. 2016) revealed an historical, single origin of the hk4S inversion. Its global distribution was shown to be particularly concentrated in Central and North-West Europe and in North America, with the ancestor of the inversion originating from Southern Europe about 5,000 years ago. The same study found polyphyletic knobless accessions widespread in Eurasia, apparently with a high density in Southern Europe (Fransz et al. 2016). Thus, the Icelandic accession is unlikely to have originated in North America, as knobless accessions are very rare there. 
A
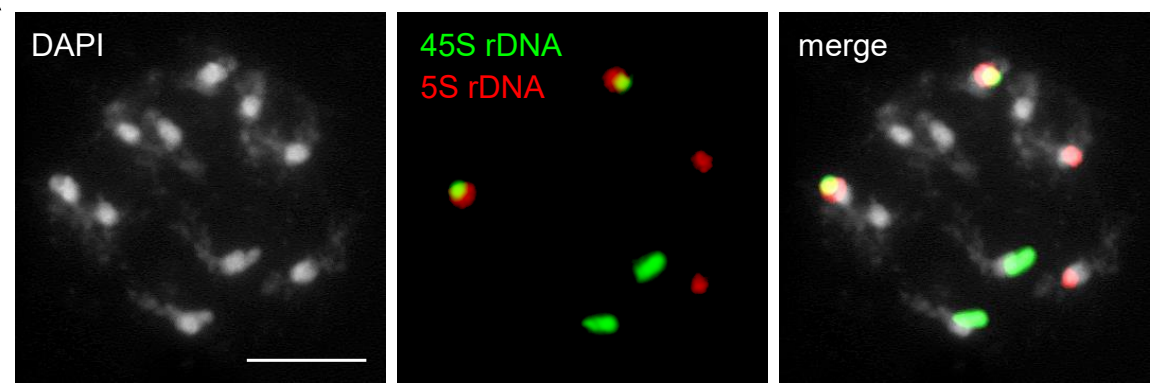

B

C

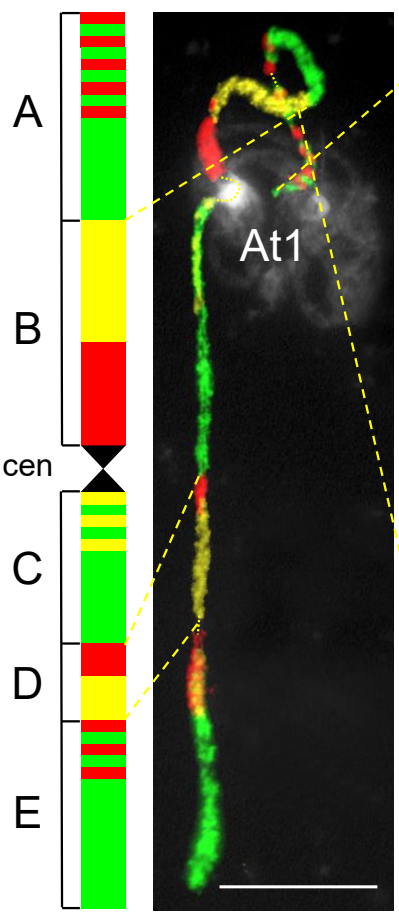

D Col Iceland
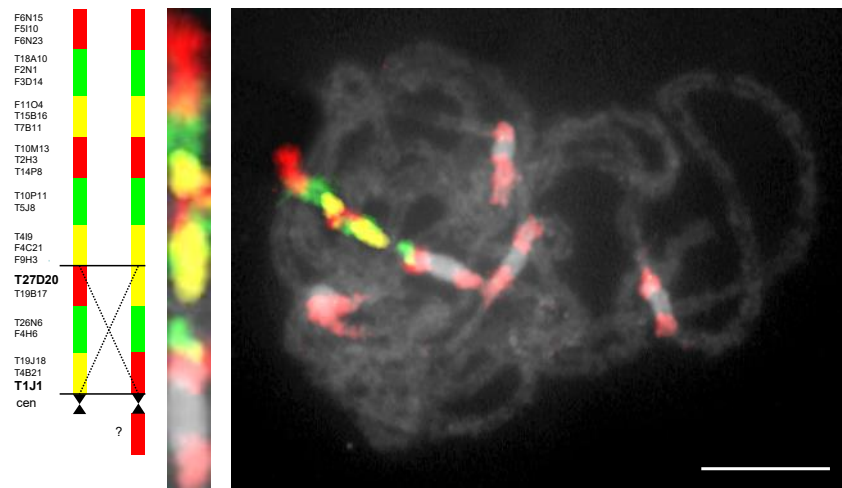

E

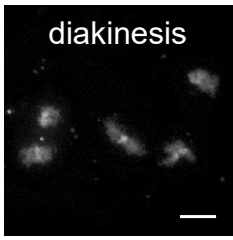

metaphase I

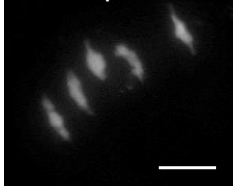


Figure 2 (page 34). Cytogenetic study of the Icelandic accession of Arabidopsis thaliana. (A) Fluorescence in situ localization of 5S (red) and 45S (green) rDNA on ten mitotic chromosomes. (B-D) Chromosome painting (CP) on pachytene chromosomes in meiosis. (B) CP of the entire chromosome At1 using 171 BAC clones. Capital letters A to E correspond to three ancestral genomic blocks. (C) A detailed CP analysis of block A ( 6.7Mb) on the upper arm of chromosome At1 using ten differently labelled BAC contigs (total 66 BAC clones). (D) Fine-scale $\mathrm{CP}$ along a $2.5-\mathrm{Mb}$ region corresponding to the upper arm of chromosome At 4 using nine differently labelled BAC contigs (total $24 \mathrm{BAC}$ clones). The position of individual BAC clones used for $\mathrm{CP}$ is shown for the Col-0 ecotype, bearing a 1.17-Mb paracentric inversion, and the Icelandic accession without the inversion. All pericentromeric regions were labelled by repeats contained in one of the BAC clones used. (E) Five bivalents in diakinesis and metaphase I. Chromosomes were counterstained with DAPI. Scale bars $=10 \mu \mathrm{m}$.

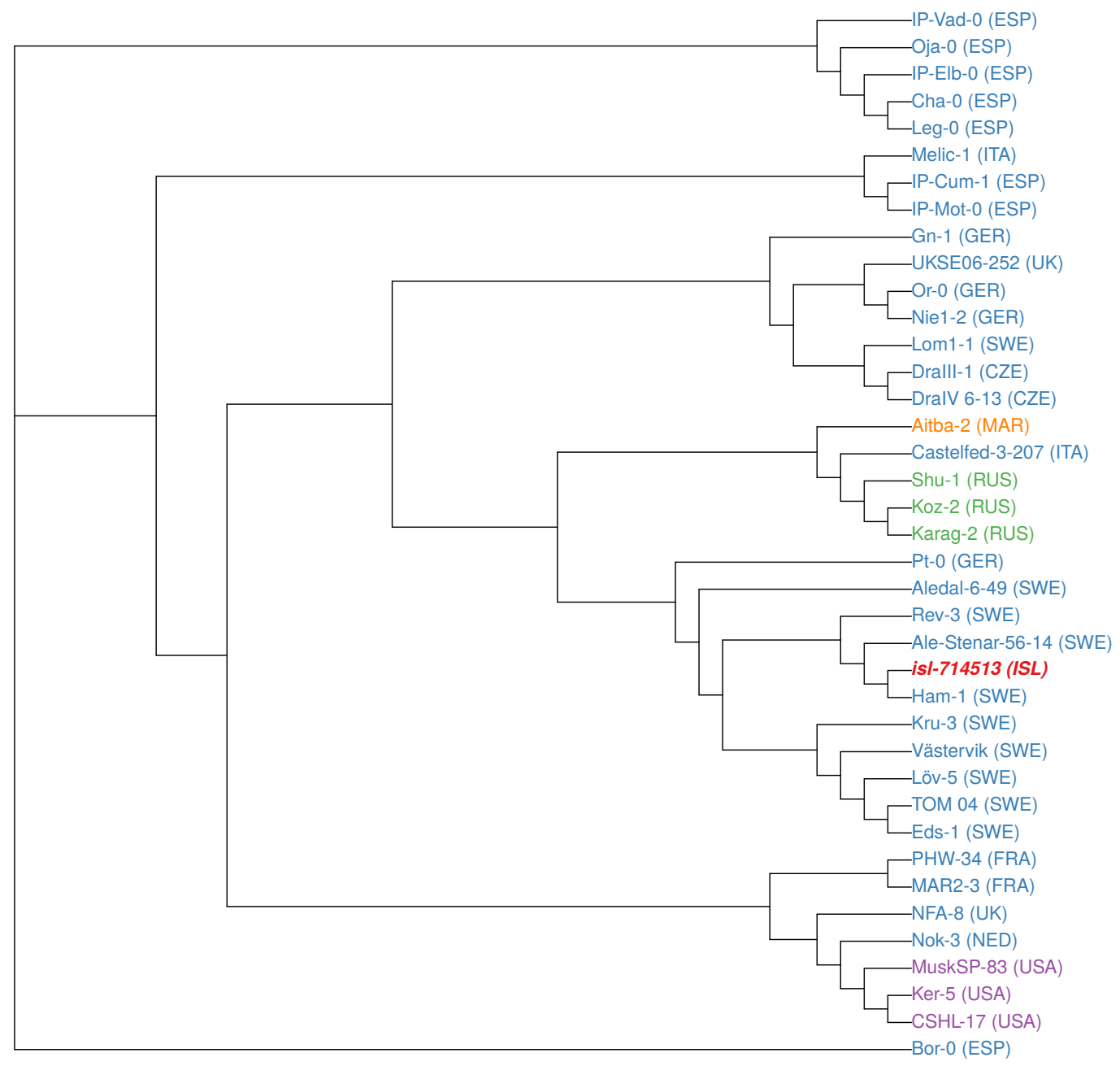

Figure 3. Neighbour joining tree for the Icelandic accession (ISL) together with 38 accessions presented with their respective country codes. Different colours represent different continents, with Iceland highlighted in red. 


\section{Genome sequencing and comparison of accessions}

Two Icelandic Arabidopsis plants were prepared for Illumina short read sequencing and the SNPmatch algorithm was used to genotype the samples and to identify their closest relatives. We found that the two Icelandic plants matched perfectly with each other with a score of 0.99 , indicating and confirming that they are from the same population. The SNPmatch identified the Swedish accession Ham-1 with a score of 0.86 as the closest match for both plants (Figure 3).

This low score of 0.86 suggests that (i), the plants are not $A$. thaliana, (ii), the plants are $A$. thaliana but derived from a recent cross instead of an inbred line or, (iii), the plants are A. thaliana but not present in the global panel of the highquality sequenced genomes from natural inbred lines (The 1001 Genomes Consortium 2016). We can exclude option (i), based on the botanical description, the cytogenetic investigation and the divergence analysis. We also performed genotyping analysis to identify homozygous windows in search of potential parent(s) in case of a recent cross. As we found no windows that perfectly match accessions in the global genomes panel, option (ii) can also be excluded. The only explanation left is option (iii), that the Icelandic A. thaliana and a representative of its origin are not present in the 1,001 Genomes panel of global $A$. thaliana accessions.

The present study reveals a closer relationship between the Icelandic accession and Swedish populations (representing Scandinavia) than to mainland European accessions (Figure 3 ). It is not surprising that northern populations of $A$. thaliana are differentiated genetically from other European clusters (Nordborg et al. 2005, Francois et al. 2008, Long et al. 2013). Molecular studies (e.g. Alsos et al. 2015) have shown that numerous European vascular plant species migrated, post-glacially, northward and/ or westward from Scandinavia across the North Atlantic islands, including Iceland, for example Arabis alpina L. However, it seems unlikely that the Icelandic accession has only recently arrived from Scandinavia, due to the poor match with present-day Swedish accessions in the $A$. thaliana 1001 set mentioned above. The species may have either previously existed in Iceland for a very long time and thus it has diverged considerably from the mainland accessions, or the Icelandic accession originates from a place where no representative sequence currently exists.

The possibility that $A$. thaliana has existed in Iceland for any length of time is very unlikely, as, prior to the present discovery, it has never been found anywhere in Iceland. The Icelandic Institute of Natural History (www.ni.is) has, for several decades, regularly mapped the occurrence and distribution of all 452 natural vascular plant species in $10 \times 10 \mathrm{~km}^{2}$ grids (Icelandic Institute of Natural History 2016). Furthermore, the whole vegetated area of Iceland was density-mapped (Flora of Iceland 2016b) based on the system of $5 \times 5 \mathrm{~km}^{2}$ grids (National Land Survey of Iceland 2016). No record of A. thaliana exists in these lists. No record of A. thaliana existed in the Icelandic AMNH and ICEL herbaria either (Pawel Wasowicz, pers. comm.), until the present study.

Taking into account the strong isolation by distance described among $A$. thaliana populations across Europe (Platt et al. 2010, The 1001 Genomes Consortium 2016), the genetic similarity of the Icelandic and Swedish accessions suggests that the origin of this new population is most likely located in Northern Europe. However, given the substantial differentiation found between the Icelandic accession and all accessions included in the current panel of sequenced accessions, the geographical location from which the Icelandic accession originated remains unknown.

\section{ACKNOWLEDGEMENTS}

This work was supported by EEA collaborative grant number EHP-CZ07-MOP-1-1052014. We would like to thank Magnus Nordborg from the Gregor Mendel Institute, Austrian Academy of Sciences, Vienna, for providing the sequencing facilities. We also thank Pawel Wasowicz from the Icelandic Institute of Natural 
History, Akureyri Division, for processing and depositing the voucher specimens in the AMNH Herbarium.

\section{REFERENCES}

Alsos IG, Ehrich D, Eidesen PB, Solstad H, Westergaard KB, Schonswetter P, Tribsch A, Birkeland S, Elven R \& Brochmann C 2015. Long-distance plant dispersal to North Atlantic islands: Colonization routes and founder effects. AoB Plants 7, plv036.

doi: http://dx.doi.org/10.1093/aobpla/plv036.

Al-Shehbaz IA \& O'Kane SL 2002. Taxonomy and phylogeny of Arabidopsis (Brassicaceae). In: The Arabidopsis Book 1: e0001. The American Society of Plant Biologists.

doi: http://dx.doi.org/10.1199/tab.0001

Ball PW 1993. Arabidopsis. In: Tutin TG, Burges NA, Chater AO, Edmondson JR, Heywood VH, Moore DM, Valentine DH, Walters SM \& Webb DA (eds.) Flora Europaea, $2^{\text {nd }}$ edition. Cambridge University Press, Cambridge, pp. 322-323.

Baym M, Kryazhimskiy S, Lieberman TD, Chung H, Desai MM \& Kishony R 2015. Inexpensive multiplexed library preparation for megabase-sized genomes. PLoS One 10(5): e0128036. doi: http://dx.doi.org/10.1371/journal.pone.0128036.

Baskin JM \& Baskin CC 1972. Ecological life cycle and physiological ecology of seed germination of Arabidopsis thaliana. Canadian Journal of Botany 50, 353-360.

Flora of China 2016. Arabidopsis thaliana (Linnaeus) Heynhold in Holl \& Heynhold. Accessed 3.11.2016 at http://www.efloras.org/florataxon.aspx?flora $\mathrm{id}=2 \&$ taxon_id=200009201.

Flora of Iceland 2016a.Arabidopsis petraea (L.) Dorof. - Melablóm [Arabidopsis petraea (L.) Dorof. - Northern Rock-cress]. Accessed 11.10.2016 at http://www.floraislands.is/cardapet. html. [In Icelandic].

Flora of Iceland 2016b. Blómplöntur [Flowering plants]. Accessed 29.11.2016 at http://www. floraislands.is/blom.html. [In Icelandic].

Francois O, Blum MGB, Jakobsson M \& Rosenberg NA 2008. Demographic history of European populations of Arabidopsis thaliana. PLoS Genetics 4: e1000075.

doi: http://dx.doi.org/10.1371/journal.pgen.1000075.
Fransz $\mathbf{P}$, Armstrong $\mathrm{S}$, Alonso-Blanco C, Fischer TC, Torres-Ruiz RA\& Jones G 1998. Cytogenetics for the model system Arabidopsis thaliana. The Plant Journal 13, 867-876.

doi: http://dx.doi.org/10.1046/j.1365-

313X.1998.00086.X.

Fransz P, Linc G, Lee CR, Aflitos SA, Lasky JR, Toomajian C, Ali H, Peters J, van Dam P, Ji X, Kuzak M, Gerats T, Schubert I, Schneeberger K, Colot V, Martienssen R, Koornneef M, Nordborg M, Juenger TE, de Jong H \& Schranz ME 2016. Molecular, genetic and evolutionary analysis of a paracentric inversion in Arabidopsis thaliana. The Plant Journal 88, 159-178.

doi: http://dx.doi.org/10.1111/tpj.13262.

Hoffmann MH 2002. Biogeography of Arabidopsis thaliana (L.) Heynh. (Brassicaceae). Journal of Biogeography 29, 125-134.

doi: http://dx.doi.org/10.1046/j.1365-2699.2002.00647.x.

Icelandic Institute of Natural History 2016. Plöntuvefsjá [Search tool for plant name and distribution]. Accessed 31.10.2016 at http://vefsja. ni.is/website/plontuvefsja/. [InIcelandic].

Koornneef M \& Meinke D 2010. The development of Arabidopsis as a model plant. The Plant Journal 61, 909-921.

doi: http://dx.doi.org/10.1111/j.1365-

313X.2009.04086.x.

Koornneef M, Fransz $P$ \& de Jong H 2003. Cytogenetic tools for Arabidopsis thaliana. Chromosome Research 11, 183-194. https://ink. springer.com/article/10.1023/A:1022827624082.

Kristinsson H, porvaldsdóttir EG \& Steindórsson B 2007. Vöktun válista plantna 2002 - 2006 [Monitoring endangered plant species in Iceland 2002 - 2006]. Fjölrit Náttúrufroeðistofnunar 50, 50-51. [In Icelandic].

Kristinsson H 2008. Íslenskt plöntutal - Blómplöntur og byrkningar [Flowering plants and ferns of Iceland]. Fjölrit Náttúrufrceðistofnunar 51, 13-14. [In Icelandic].

Kristinsson H 2015. Útbreiðslumynstur og aldur íslensku flórunnar [Distribution patterns and age of the Icelandic flora]. Náttúrufrceðingurinn 85, 121133. [In Icelandic].

Long Q, Rabanal FA, Meng D, Huber CD, Farlow A, Platzer A, Zhang Q, Vilhjálmsson BJ, Korte A, Nizhynska V, Voronin V, Korte P, Sedman L, 
Mandáková T, Lysak MA, Seren U, Hellmann I \& Nordborg M 2013. Massive genomic variation and strong selection in Arabidopsis thaliana lines from Sweden. Nature Genetics 45, 884-890.

doi: http://dx.doi.org/10.1038/ng.2678.

Maluszynska J \& Heslop-Harrison JS 1991. Localization of tandemly repeated DNA sequences in Arabidopsis thaliana. The Plant Journal 1, 159166.

Mandáková T \& Lysak MA 2016a. Chromosome preparation for cytogenetic analyses in Arabidopsis. Current Protocols in Plant Biology 1, 1-9. doi: http://www10.1002/cppb.20009.

Mandáková T \& Lysak MA 2016b. Painting of Arabidopsis chromosomes with chromosomespecific BAC clones. Current Protocols in Plant Biology 1, 359-371. doi: http://www10.1002/cppb.20022.

Meyerowitz EM \& Pruitt RE 1985. Arabidopsis thaliana and plant molecular genetics. Science 229, 1214-1218. URL: http://www.jstor.org/ stable/1696024.

Murata M, Heslop-Harrison JS \& Motoyoshi F 1997. Physical mapping of the 5S ribosomal RNA genes in Arabidopsis thaliana by multi-color fluorescence in situ hybridization with cosmid clones. The Plant Journal 12, 31-37.

National Land Survey of Iceland 2016. Reitakerfi Íslands. Accessed 29.11.2016 at http://www.lmi.is/ reitakerfi-islands/. [InIcelandic].

Náttúran 2016. Deildartunguhver i Reykholtsdal. [Deildartunguhver in Reykholtsdalur]. Accessed 14.10.2016 at http://www.husafell.is/islenska/umhusafell/natturan/. [InIcelandic].

Nordborg M, Hu TT, Ishino Y, Jhaveri J, Toomajian C, Zheng H, Bakker E, Calabrese P, Gladstone J, Goyal R, Jakobsson M, Kim S, Morozov Y, Padhukasahasram B, Piagnol V, Rosenberg NA, Shah C, Wall JD, Wang J, Zhao K, Kalbfleisch T, Schulz V, Kreitman M \& Bergelson $\mathbf{J}$ 2005. The pattern of polymorphism in Arabidopsis thaliana. PLoS Biology 3, e196. doi: http://dx.doi.org/10.1371/journal.pbio.0030196.

NPGS 2016. The U.S. National Plant Germplasm System (NPGS): Arabidopsis thaliana (L.) Heynh. Accessed 7.12.2016 at https://npgsweb.ars-grin. gov/gringlobal/taxonomydetail.aspx?3769.
O'Gorman EJ, Benstead JP, Cross WF, Friberg N, Hood JM, Johnson PW, Sigurdsson BD \& Woodward G 2014. Climate change and geothermal ecosystems: Natural laboratories, sentinel systems, and future refugia. Global Change Biology 20, 3291-3299.

doi: http://dx.doi.prg/10.1111/gcb.12602.

Pecinka A, Schubert V, Meister A, Kreth G, Klatte M, Lysak MA, Fuchs J \& Schubert I 2004. Chromosome territory arrangement and homologous pairing in nuclei of Arabidopsis thaliana are predominantly random except for NOR-bearing chromosomes. Chromosoma 113, 258-269.

doi: http://dx.doi.org/10.1007/s00412-004-0316-2.

Pisupati R, Reichardt I, Seren U, Korte P, Nizhynska V, Kerdaffrec E, Uzunova K, Rabanal F, Filiault DL \& Nordborg M 2017. Verification of Arabidopsis stock collections using SNPmatchan algorithm to genotyping high-plexed samples. Cold Spring Harbor Laboratory - bioRxiv. doi: https://doi.org/10.1101/109520.

Platt A, Horton M, Huang YS, Li Y, Anastasioo AE, Mulyati NW, Agren J, Bossdorf O, Byers D, Donohue K, Dunning M, Holub EB, Hudson A, Le Corre V, Loudet O, Roux F, Warthmann N, Weigel D, Rivero L, Scholl R, Nordborg M, Bergelson J \& Borevitz JO 2010. The scale of population structure in Arabidopsis thaliana. doi: http://dx.doi.org/10.1371/journal.pgen.1000843.

Rédei GP 1975. Arabidopsis as a genetic tool. Annual Review of Genetics 9, 111-127.

The Arabidopsis Information Resource 2016. TAIR 10.0 genome sequence, released November 2010. Accessed October 2016 at https://seqviewer. arabidopsis.org, on www.arabidopsis.org.

The Arabidopsis Genome Initiative 2000. Analysis of the genome sequence of the flowering plant Arabidopsis thaliana. Nature 408, 796-815. doi: http://dx.doi.org/10.1038/35048692.

The 1001 Genomes Consortium 2016. 1,135 genomes reveal the global pattern of polymorphism in Arabidopsis thaliana. Cell 166, 481-491. doi: http://dx.doi.org/10.1016/j.cell.2016.05.063.

Manuscript received 9 December 2016 Accepted 16 March 2017 